\title{
A DPSIR and SAF Analysis of Water Insecurity in Lake Chad Basin, Central Africa
}

\author{
Lukman Adeboye Soboyejo ${ }^{1}$, Ahmad Mojisola Sakinat ${ }^{1}$, and Abayomi Oluwatobiloba Bankole ${ }^{2}$ \\ ${ }^{1}$ Department of Biological, Geological, and Environmental Science, University of Bologna, \\ Ravenna Campus, Emilia-Romagna, 48123, Italy \\ ${ }^{2}$ Department of Water Resources and Agricultural Meteorology, \\ Federal University of Agriculture, 2240, Abeokuta, Nigeria
}

Correspondence: Lukman A. Soboyejo (lukeng200@gmail.com)

Published: 16 November 2021

\begin{abstract}
Lake Chad is a transboundary freshwater body located in the extreme south of the Sahara Desert. Many centuries ago, the synergies between nature and human activities in the basin were in harmony; and nowadays, the manifestation of unsustainable human activities and drier climate in the basin is now evident. This study assesses the water insecurity and associated environmental issues in the area using the combined DriverPressure-State-Impact-Response (DPSIR) and System-Approach-Framework (SAF) frameworks. In achieving this, we conducted literature review to establish the major effects and possible consequences of water scarcity in the area. The SAF defines the Lake boundaries and eventually links the active stakeholders involved. On the other hand, the DPSIR reveals that about $90 \%$ of inhabitants depends on agriculture, with warming (temperature) significantly increasing in the basin $\left(0.22^{\circ} \mathrm{C}\right.$ per decade $)$ - socio-economic and natural Drivers respectively - as well as increase in population. Pressures include input from irrigation systems, river-flow modification, limited rainfall, and prolonged drought periods. These pressures have led to change in the state of Lake Chad, like freshwater shortages and loss of ecological status. Impacts on human welfares includes mass displacement, unemployment, paralyzed socio-economic activities, and social unrest. The societal-Response has prompted various measures like the launch of campaigns and awareness, planned Inter-Basin-Water-Transfer (IBTW), and several policy changes for better governance. Conclusively, the restoration of Lake Chad solely depends on climate conditions and management policies. However, this study recommends the prioritization of monitoring systems, water-allocation plans, ecological plans, and modelling tools for better decision processes.
\end{abstract}

\section{Introduction: Issue Identification}

Over 11700 years ago, the surface area of Lake Chad covered approximately $350000 \mathrm{~km}^{2}$. At that time, the Lake's surface area was almost equal in size to the Caspian Sea, which is the largest Lake in the world (UNEP, 2004). The Lake Chad Basin (LCB) was a thriving socio-economic centre for the entire Sahel basin because of the lake (Vivekananda et al., 2019). However, in the last 50 years, Lake Chad and its river catchments are being withdrawn in an unsustainable way under unfavourable climate conditions (UNEP, 2004). So, the Lake was completely separated into two parts (after 1973), demarcated in the middle by a shoal barrier, and still fluctuating in size (Lemoalle et al., 2012).
Inhabitants whose socio-economic activities depend on the Lake ( $>30$ million people) started to witness a downturn in socio-economic activities, loss of ecological integrity, and loss of prominent fishing communities.

The change of state of Lake Chad prompted the coming together of the Lake Chad Basin Commission (LCBC) member states in 1964 to manage and rescue the shrinking freshwater Lake (Lemoalle et al., 2012). Despite the joint management, the waterbody still shrunk to $2500 \mathrm{~km}^{2}$ (in 1987) but later increased to almost $14000 \mathrm{~km}^{2}$ (in 2013) due to slight increase in rainfall between 2000 and 2019 (Lemoalle and Magrin, 2014; Vivekananda et al., 2019). The significant rise in the ground and river water levels is still not evident in the 
area (LCBC, 2016; International Conference on Lake Chad, 2018). Sadly enough, the future trend of rainfall in the Sahel region remains highly uncertain (Hoegh-Guldberg et al., 2018). This has generated misconceptions among the top regulators, influencers, researchers, and scientific communities as to whether Lake Chad will disappear or not. Measures (like dam projects, strategic action plans, and more) have been put in place, but have not yielded satisfactory outcomes, persuading the LCBC to re-visit the long-neglected project in 2018 (Inter-Basin Water Transfer - IBWT). This is seen as feasible and viable option by some Influencers and Regulators as a form of hope to revitalize Lake Chad (see Sayan and Nagabhatla, 2020 for detailed explanation).

\section{Aim and Objectives}

The purpose of this study is to analyse water insecurity in LCB by shedding more light on the causes and effects. The understanding of the problem is a significant prerequisite for tackling it. This study will go a long way in presenting a clearer picture of the problem to decision-makers, stakeholders, and co-researchers. The study objectives include (i) identifying the main actors responsible for the management of the shared water resources in the area, and (ii) determining the Drivers, the Pressures on Lake Chad, the present State, the Impact on human economic and social welfare, and the Responses.

\section{Methodology}

The methodology involves the use of SAF (explained in Newton and Elliott, 2016) and D(A)PSI(W)R framework (remodified by Elliott et al., 2017). These frameworks were combined to indicate water insecurity challenges in the LCB. In achieving this, we conducted literature review that included scholarly articles, regional and international assessment reports. We included climate change as crucial natural driver for this study, because Lake Chad's water resource is highly sensitive to climate anomalies. SAF was used to identify the main issues, define the boundary, and mapping out stakeholders. On the other hand, the D(A)PSI(W)R was used to identify the Driving forces, Human Activities, Pressures, physical and ecological States, Impacts (on Human-Welfare), and Responses.

\section{Boundary Definition: Study Area}

Lake Chad is located in West Central Africa and lies between latitude 6 and $24^{\circ} \mathrm{N}$ and longitude 7 and $24^{\circ} \mathrm{E}$, covering about $2434000 \mathrm{~km}^{2}$ ( $8 \%$ of African landmass), but the hydrologically active land portion covers about $966955 \mathrm{~km}^{2}$ (Odada et al., 2005; UNEP, 2004) (Fig. 1).

\section{Discussion on Water Insecurity Indicators}

\subsection{System Approach Framework (SAF)}

According to Newton and Elliott (2016), stakeholder identification could be divided into six groups. In this study, five actors are considered: Extractors, Beneficiaries, Affectees, Regulators, and Influencers (see Table 1).

\subsection{D(A)PSI(W)R Framework}

\subsubsection{Drivers (human activities, climate change, and population growth)}

Water insecurity in the LCB is closely linked to climate change, migration, and socio-economic development. In Sub-Saharan Africa, agriculture as a major socio-economic driver of water scarcity accounts for about $60 \%$ of the human occupation (Miletto et al., 2017). More so, in the LCB, about $90 \%$ of agricultural jobs depend on the Lake for survival (FAO, 2017).

Another crucial factor is climate change, the inter-annual precipitation of LCB is slightly increasing in trend (Nagarajan et al., 2018) with future uncertainty (Hoegh-Guldberg et al., 2018). The first localised climate prediction study conducted by Rashid et al. (2019) showed that the annual temperature in the area has increased with a trend value of $0.22^{\circ} \mathrm{C}$ per decade, while the precipitation trend has slightly decreased with a $14 \mathrm{~mm}$ per decade trend value. In the nearest future (2026-2035), the basin's temperature will increase by 0.6 to $1.6^{\circ} \mathrm{C}$, while precipitation will decrease by $5 \%$ to $16 \%$.

Apropos to demographic growth, Sub-Saharan Africa will mark almost 3.8 billion ( 11 billion globally) by 2100 . The growth statistics means that 1 out of 3 people across the globe will come from Sub-Saharan Africa (United Nations, 2019). This significant rise will certainly alter the way people advance water scarcity in the region.

\subsubsection{Pressure}

Intensive irrigation farming and other forms of water withdrawal practices were predominant in the basin between 1953 and 1979. The amount of water withdrawn from the Lake for irrigation alone quadrupled between 1983 and 1994 (Coe and Foley, 2001). In these periods, the volume of water dropped significantly $\left(2500 \mathrm{~km}^{2}\right.$ in 1987) and water demands for irrigation doubled with expanding arable land (GWP, 2013), thus leading to direct human modification on tributaries.

\subsubsection{State of the Environment}

The aerial view of Lake Chad (Fig. 2) shows considerable change in the state and volume of water. Niger has access only to the northern part of the Basin and contains water 


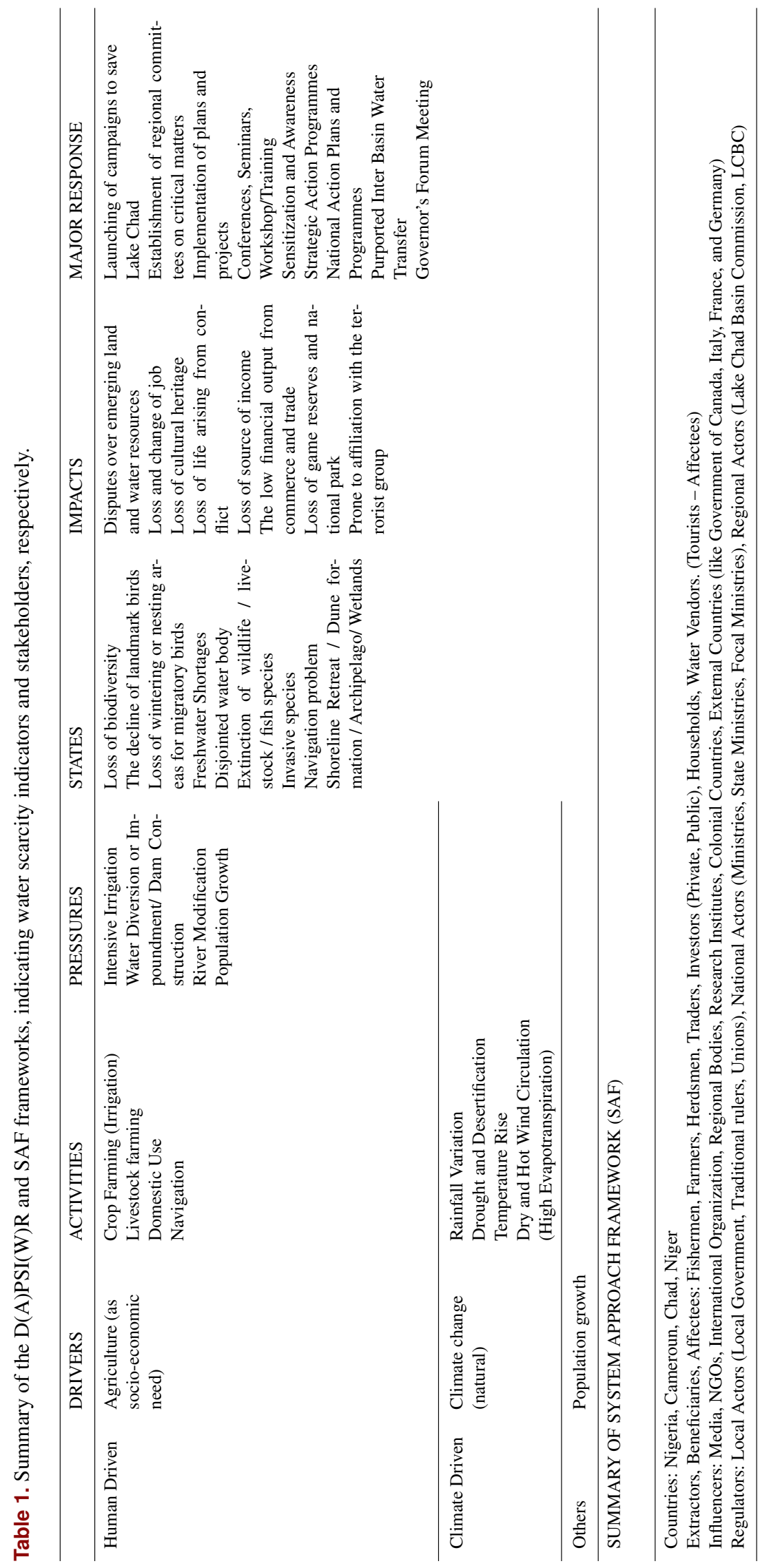



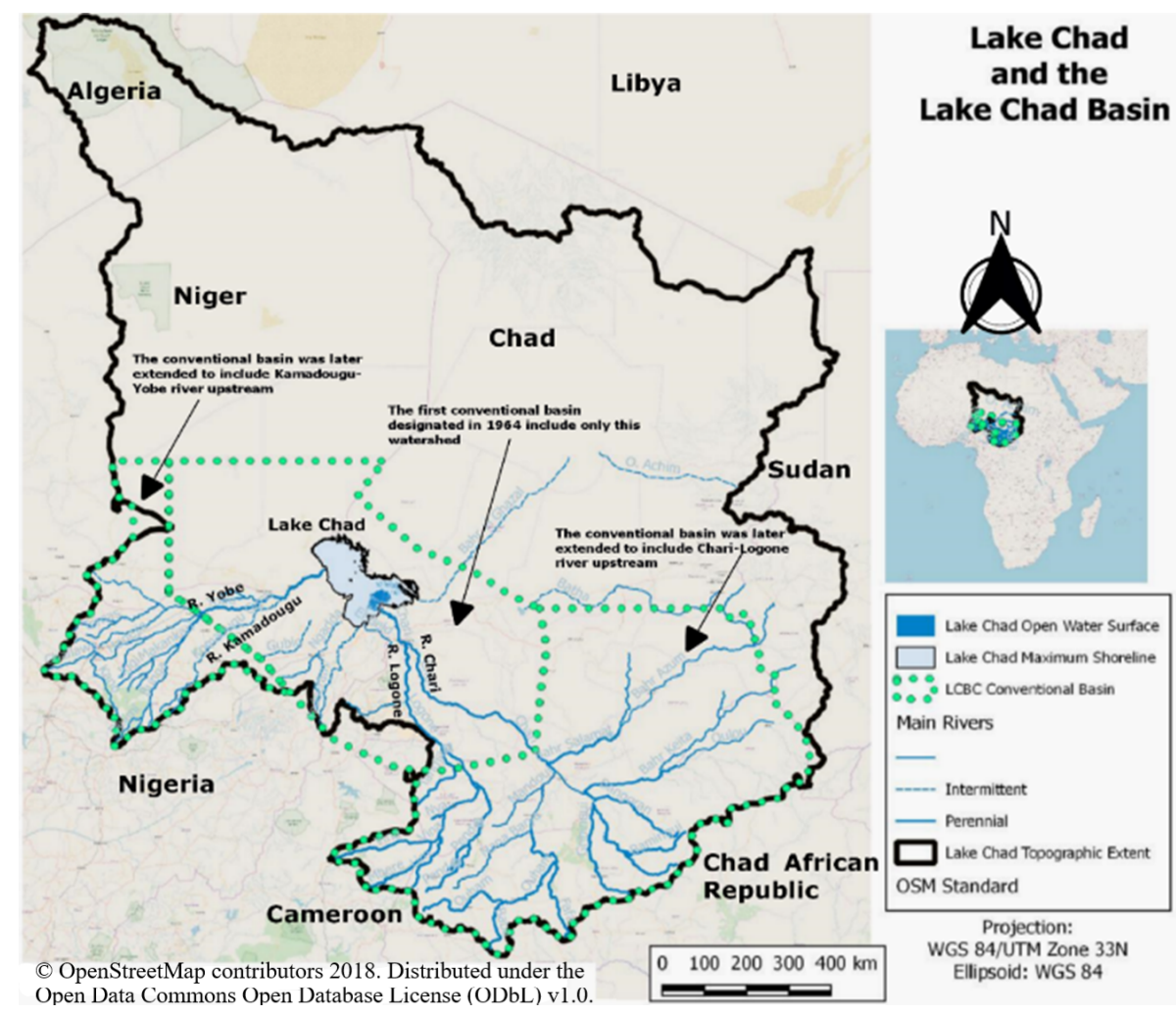

Figure 1. A map showing the conventional basin and the Lake Chad. Modified from International Conference on Lake Chad (@) OpenStreetMap contributors 2018. Distributed under the Open Data Commons Open Database License (ODbL) v1.0).

every wet and dry season compared to the drought periods when both seasons often dry out completely (Binh et al., 2020; Vivekananda et al., 2019). Nigeria has a small portion of water points, while Cameroon and Chad still have more water within their territories. However, the extent and variation of surface water in the southern pool have maintained a stable trend since the 2000s. In contrast, the northern pool has slightly declined in extent due to annual and seasonal variability (Binh et al., 2020; Vivekananda et al., 2019). Furthermore, Binh et al. (2020), Lemoalle and Magrin (2014), Magrin (2016), and Vivekananda et al. (2019) claimed that the Lake will not disappear because the variability and extent of Lake Chad corroborates with historical and seasonal fluctuations. However, these researchers admit the negative effect of climate change on socio-economic activities, the lake water body extent and variability in space and time.

In reference to ecological status, the population of many indigenous flora and fauna species is threatened and endangered due to lowered water level (Hutchinson et al., 1992), leading to loss of ecological integrity and status.

\subsubsection{Impacts (human welfare and ecological state)}

In the Sahel region, irrigation is the only productive means by which inhabitants can settle down for a better livelihood (Miletto et al., 2017). Unfortunately, the Beneficiaries, Ex- tractors, and Affectees in each riparian country have faced severe socio-economic problems due to freshwater shortages. Many households have consistently lamented about declined socio-economic activities. Also, they have seen the Lake retreated beyond its current shoreline. As a result, family members (especially the males) have migrated to possible job recruitment places for better lives (Odada et al., 2005; Vivekananda et al., 2019).

\subsubsection{Responses}

The sudden decline of Lake Chad and the resulting impact has raised concern among riparian member states. In the face of the increasing challenges, various management steps have been taken by the Regulators and Influencers to mitigate the effects and possible consequences (see Table 1). Unfortunately, the LCBC have been struggling with finance. To avoid this, the Commission adopted multi-donor approach; whereby Regulator's source for funds from Influencers (that is, external donors), member and conventional states, and through other means like levy systems, project management remuneration, and the sale of services (Odada et al., 2005). 


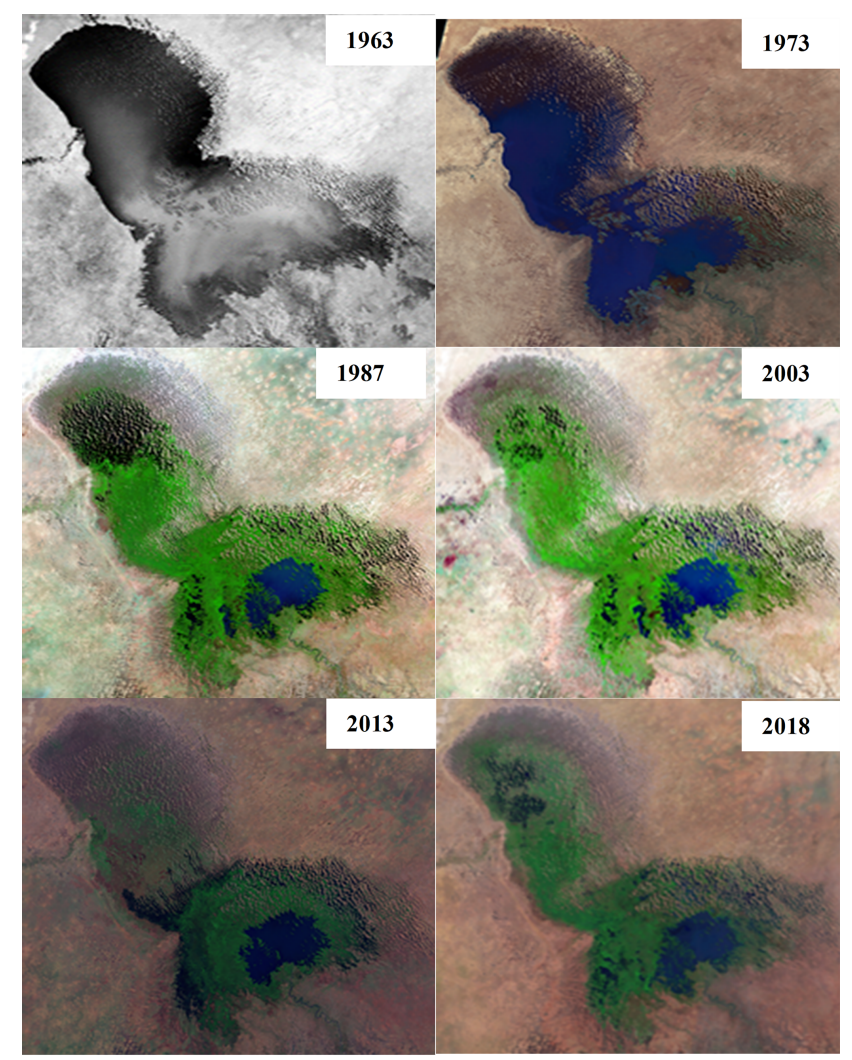

Figure 2. Chronological of changes in Lake Chad State from 1963 to 2018 (USGS, 2020).

\section{Conclusion and Recommendation}

The current surface area extent of Lake Chad is caused by the following set of Divers: population growth, human activities, and climate change, and management policies, leading to fluctuation and significant decline of the Lake. However, climate change is the primary determinant of Lake Chad's temporal and spatial water availability because of the imbalance in hydrological condition. The future recovery State of Lake Chad solely depends on future water management policies and climate change. Conclusively, we recommend the prioritization of monitoring systems, water-allocation plans and water release policy, ecological plans, and modelling tools for better decision processes.

Data availability. The manuscript is based on literature reviews and the use of assessment frameworks. SAF Framework - http:// www.coastal-saf.eu/ (Coastal SAF, 2021). DPSIR Framework - see Elliott et al. (2017) for detailed explanation on usage.

Author contributions. Conceptualization of methodology, formal analysis, investigation, and writing (original draft preparation) were performed by the lead author LAS, while the final review and editing were carried out by LAS, AMS, AOB. All authors have read and agreed to the published version of the manuscript.

Competing interests. The contact author has declared that neither they nor their co-authors have any competing interests.

Disclaimer. Publisher's note: Copernicus Publications remains neutral with regard to jurisdictional claims in published maps and institutional affiliations.

Special issue statement. This article is part of the special issue "Hydrology of Large River Basins of Africa". It is a result of the 4th International Conference on the "Hydrology of the Great Rivers of Africa", Cotonou, Benin, 13-20 November 2021.

Acknowledgements. My [Lukman Adeboye Soboyejo] sincere gratitude goes to all Water and Coastal Management (WaCoMa) coordinators (https://wacoma.unibo.it/home.php, last access: 21 January 2021) as well as the European Union for the Erasmus Mundus Joint Master Degree (EMJMD) Programme and Scholarship provided as part of the 2018-2020 cohort at the University of Bologna - Italy, the University of Cadiz - Spain, and the University of Algarve - Portugal. More specifically, I am grateful to Alice Newton for exposing WACOMA students to DPSIR and SAF frameworks during the course of study, which has yielded this conference paper.

\section{References}

Binh, P. D., Sylvestre, F., Papa, F., Frappart, F., Bouchez, C., and Crétaux, J.-F.: The Lake Chad hydrology under current climate change, Scientific Reports, 10, 5498, https://doi.org/10.1038/s41598-020-62417-w, 2020.

Coastal SAF: Homepage, available at: http://www.coastal-saf.eu/, last access: 23 January 2021.

Coe, M. T. and Foley, J. A.: Human and natural impacts on the water resources of the Lake Chad basin, J. Geophys. Res.-Atmos., 106, 3349-3356, https://doi.org/10.1029/2000JD900587, 2001.

Elliott, M., Burdon, D., Atkins, J. P., Borja, A., Cormier, R., de Jonge, V. N., and Turner, R.: "And DPSIR Begat DAPSI(W)R(M)!" - A Unifying Framework for Marine Environmental Management, Mar. Pollut. Bull., 118, 27-40, https://doi.org/10.1016/j.marpolbul.2017.03.049, 2017.

Food and Agriculture Organization (FAO): Lake Chad Basin - Situation report July 2017, FAO - Food and Agriculture Organization of the United Nations, available at: https://www.fao.org/ resilience/resources/resources-detail/en/c/1013218/ (last access: 21 October 2021), 2017.

Global Water Partnership (GWP): Transboundary Groundwater fact sheet, The Lake Chad Basin Aquifer System, Global Water Partnership, Global Secretariat, Sweden, 2013.

Hoegh-Guldberg, O., Jacob, D., Taylor, M., Bindi, M., Brown, S., Camilloni, I., Diedhiou, A., Djalante, R., Ebi, K. L., Engelbrecht, F., Guiot, J., Hijioka, Y., Mehrotra, S., Payne, A., Seneviratne, S. I., Thomas, A., Warren, R., and Zhou, G.: Impacts of $1.5^{\circ} \mathrm{C}$ 
Global Warming on Natural and Human Systems, in: Global warming of $1.5^{\circ} \mathrm{C}$. An IPCC Special Report on the impacts of global warming of $1.5^{\circ} \mathrm{C}$ above pre-industrial levels and related global greenhouse gas emission pathways, in the context of strengthening the global response to the threat of climate change, edited by: Masson-Delmotte, V., Zhai, P., Pörtner, H. O., Roberts, D., Skea, J., Shukla, P. R., Pirani, A., Moufouma-Okia, W., Péan, C., Pidcock, R., Connors, S., Matthews, J. B. R., Chen, Y., Zhou, X., Gomis, M. I., Lonnoy, E., Maycock, T., Tignor, M., and Waterfield, T., World Meteorological Organization Technical Document, Geneva, Switzerland, 2018.

Hutchinson, C. F., Warshall, P., Arnould, E. J., and Kindler, J.: Development in Arid Lands Lessons from Lake Chad, Environ. Sci. Policy Sustain. Dev., 34, 16-43, https://doi.org/10.1080/00139157.1992.9931452, 1992.

International Conference on Lake Chad: Saving the Lake Chad to revitalize the Basin's ecosystem for sustainable livelihood, security, and development, available at: https://waterresources.gov. ng/lake-chad-conf/ (last access: 20 October 2021), 2018.

Lake Chad Basin Commission (LCBC): Report on the State of the Lake Chad Basin Ecosystem, GIZ Joint Report, Commission du Bassin du Lac Tchad (CBLT), Deutsche Gesellschaft für Internationale Zusammenarbeit (GIZ) GmbH, Bonn and Eschborn, Germany, 233 pp., 2016.

Lemoalle, J., Bader, J.-C., Leblanc, M., and Sedick, A.: Recent changes in Lake Chad: observations, simulations and management options (1973-2011), Glob. Planet. Change, 80-81, 247254, https://doi.org/10.1016/j.gloplacha.2011.07.004, 2012.

Lemoalle, J. and Magrin, G.: Le développement du lac Tchad / Development of Lake Chad: Situation actuelle et futurs possibles / Current Situation and Possible Outcomes, Expertise collégiale, IRD Éditions, Marseille, France, 216 pp., 2014.

Magrin, G.: The disappearance of Lake Chad: history of a myth, J. Polit. Ecol., 23, 204-222, https://doi.org/10.2458/v23i1.20191, 2016.

Miletto, M., Caretta, M. A., Burchi, F. M., and Zanlucchi, G.: Migration and its interdependencies with water scarcity, gender, and youth employment, UNESCO Publishing, Paris, France, 34 pp., 2017.
Nagarajan, C., Pohl, B., Rüttinger, L., Sylvestre, F., Vivekananda, J., Wall, M., and Wolfmaier, S.: Climate-fragility profile: : Lake Chad basin, Adelphi research gemeinnützige $\mathrm{GmbH}$, Berlin, Germany, 31 pp. 2018.

Newton, A. and Elliott, M.: A Typology of Stakeholders and Guidelines for Engagement in Transdisciplinary, Participatory Processes, Front. Mar. Sci., 3, 230, https://doi.org/10.3389/fmars.2016.00230, 2016.

Odada, E., Oyebande, L., and Oguntola, A. J.: Lake Chad: experience and lessons learned brief, Lake Environment Committee Foundation, Kusatsu, Japan, 18 pp., 2005.

Rashid, M., Shaofeng, J., and Zhu, W.: Analysis of climate variability, trends, and prediction in the most active parts of the Lake Chad basin, Africa, Scientific Reports, 9, 6317, https://doi.org/10.1038/s41598-019-42811-9, 2019.

Sayan, R. C. and Nagabhatla, N.: Soft Power, Discourse Coalitions, and the Proposed Interbasin Water Transfer Between Lake Chad and the Congo River, Water Altern., 13, 752-778, 2020.

United Nation Environment Programme (UNEP): Lake Chad Basin, edited by: Fortnam, M. P. and Oguntola, J. A., Global International Water Assessment (GIWA - Regional Assessment-43), University of Kalmar, Kalmar, Sweden, 2004.

United Nations (Department of Economic and Social Affairs): Population Division: World Population Prospects 2019 - Highlights, ST/ESA/SER.A/423, United Nation Publisher, New York, USA, 2019.

United States Geological Survey (USGS): Lake Chad, West Africa, Earth shots: Satellite Images of Environmental Change, available at: https://earthshots.usgs.gov/earthshots/ Lake-Chad-West-Africa\#ad-image, last access: 15 December 2020 .

Vivekananda, J., Wall, M., Sylvestre, F., Nagarajan, C., and Brown, O.: Shoring up Stability; Addressing Climate and Fragility Risks in the Lake Chad Region, adelphi research gemeinnützige GmbH, Berlin, Germany, 101 pp., 2019. 